\title{
Proteomic analysis of Flavobacterium psychrophilum cultured in vivo and in iron-limited media
}

\author{
B. R. LaFrentz ${ }^{1,5}$, S. E. LaPatra ${ }^{2}$, D. R. Call ${ }^{3}$, G. D. Wiens ${ }^{4}$, K. D. Cain ${ }^{1, *}$ \\ ${ }^{1}$ Department of Fish and Wildlife Resources and the Aquaculture Research Institute, University of Idaho, \\ PO Box 441136, Moscow, Idaho 83844-1136, USA \\ ${ }^{2}$ Research Division, Clear Springs Foods, Inc., PO Box 712, Buhl, Idaho 83316, USA \\ ${ }^{3}$ Department of Veterinary Microbiology and Pathology, Washington State University, 402 Bustad Hall, Pullman, \\ Washington 99164-7040, USA \\ ${ }^{4}$ United States Department of Agriculture, Agricultural Research Service, National Center for Cool and Coldwater Aquaculture, \\ 11861 Leetown Road, Kearneysville, West Virginia 25430, USA \\ ${ }^{5}$ Present address: Aquatic Animal Health Research Unit, United States Department of Agriculture, Agricultural Research Service, \\ 990 Wire Road, Auburn, Alabama 36832-4352, USA
}

\begin{abstract}
Flavobacterium psychrophilum is the etiologic agent of bacterial coldwater disease, but the pathogenic mechanisms of this important fish pathogen are not fully understood. Identifying bacterial genes of F. psychrophilum differentially expressed in vivo may lead to a better understanding of pathogenesis and provide targets for vaccine development. Therefore, the present study used a proteomic approach to identify and quantify proteins of $F$. psychrophilum following growth in vivo and under iron-limited growth conditions. As determined by 2D polyacrylamide gel electrophoresis (2D-PAGE), numerous proteins exhibited different spot intensities following culture of the bacterium in vivo, and of these, 20 were selected and identified by liquid chromatography-mass spectrometry/ mass spectrometry (LC-MS/MS) analysis and Mascot searches of the F. psychrophilum genome. Eighteen proteins exhibited increased spot intensities in vivo, and these included: several chaperone and stress proteins, gliding motility protein GldN, outer membrane protein $\mathrm{OmpH}, 2$ probable outer membrane proteins (OmpA family), probable aminopeptidase precursor, probable lipoprotein precursor, 3-oxoacyl-[acyl-carrier-protein]-reductase, and several proteins with unknown function. Two proteins exhibited decreased spot intensities in vivo and were identified as ferritin FtnA and outer membrane protein OmpA (P60). Culture of F. psychrophilum in iron-limited media resulted in similar protein spot intensity changes for 6 of the 20 proteins identified following growth in vivo. Results from the present study suggest a role of upregulated proteins in the pathogenesis of F. psychrophilum and these may represent potential vaccine candidate antigens.
\end{abstract}

KEY WORDS: Flavobacterium psychrophilum • Pathogenesis · Vaccine candidate • Bacterial coldwater disease $\cdot$ Proteomic $\cdot$ In vivo growth $\cdot$ Iron-limited growth

Resale or republication not permitted without written consent of the publisher

\section{INTRODUCTION}

Flavobacterium psychrophilum is a Gram-negative bacterium that causes bacterial coldwater disease (CWD) and rainbow trout fry syndrome. This pathogen represents a significant problem for aquaculture due to its ability to cause high mortality and subsequent economic losses, a wide geographic distribution, and an ability to infect a large number of fish species (Nema- tollahi et al. 2003). Consequently, there is a need for an effective vaccine that can be easily administered to large numbers of susceptible fish.

The success of vaccine development against a pathogen is enhanced by knowledge of host-pathogen interactions, such as the host mechanisms involved in eliciting a protective immune response and the pathogenic mechanisms or virulence factors of the pathogen. In recent years, a number of such mechanisms have 
begun to be elucidated for Flavobacterium psychrophilum. Research has demonstrated that specific antibodies are important for protection, but non-specific immune components also appear to be involved in stimulating an effective immune response (LaFrentz et al. 2002, 2003, Wiklund \& Dalsgaard 2002). It has been suggested that the pathogenicity of $F$. psychrophilum may be linked to adherence to host tissue, production of proteolytic enzymes, iron acquisition mechanisms, secretion systems, and production of lipopolysaccharide and a glycocalyx capsular layer (Nematollahi et al. 2003, Duchaud et al. 2007, Alvarez et al. 2008). However, the exact mechanisms are not fully understood.

Although an increased understanding of hostpathogen interactions related to Flavobacterium psychrophilum has been gained, the development of an efficacious vaccine has not been successful to date. There are reports of success via oral immunization of fish against CWD (Aoki et al. 2007). Nevertheless, most vaccines based on killed whole-cell preparations have been ineffective when administered using mass delivery methods that are practical for most species affected by F. psychrophilum in aquaculture (Obach \& Laurencin 1991, LaFrentz et al. 2002). Therefore, recent efforts have been aimed at identifying specific bacterial antigens to target for vaccine development. Such research has resulted in the identification of numerous proteins or specific fractions of $F$. psychrophilum (Rahman et al. 2002, Merle et al. 2003, LaFrentz et al. 2004, Massias et al. 2004, Crump et al. 2005, 2007, Dumetz et al. 2007, 2008, LaFrentz 2007, Sudheesh et al. 2007), some of which have been shown to be protective (Rahman et al. 2002, LaFrentz et al. 2004, Dumetz et al. 2006, Crump et al. 2007). These studies demonstrate the potential for identifying vaccine candidates; however, the work was performed using in vitro cultured bacteria, and our knowledge of differential gene expression by F. psychrophilum grown in vivo is lacking.

The in vitro culture environment is artificial and does not necessarily represent in vivo conditions. One example of this relates to the availability of iron, which is an essential element for the growth of bacteria. Iron is readily available in most bacteriological media; however, iron is limited in vivo due to host production of iron-binding proteins such as transferrin and lactoferrin (Otto et al. 1992). Brown et al. (1988) suggested that bacteria grown in vivo should be analyzed in studies aimed at identifying virulence factors and vaccine candidate antigens, because expression of these factors may be altered in the in vitro environment. Several studies have taken this approach and identified differences in bacterial pathogens by comparing cells grown in vitro and in vivo, including differences in carbohydrate components (Thornton et al. 1993, Wang et al.
2004, Poobalane et al. 2008) and protein regulation (Thornton et al. 1993, Colquhoun \& Sorum 1998, Bakopoulos et al. 2004, Ebanks et al. 2004, Poobalane et al. 2008).

A possible explanation for the lack of protection following immunization with killed whole-cell Flavobacterium psychrophilum preparations is that important virulence determinants and/or protective components of the bacterium are not produced during in vitro culture in standard bacteriological media. This has been suggested for fish pathogens such as Aeromonas salmonicida (Thornton et al. 1993) and Photobacterium damsela subsp. piscicida (Bakopoulos et al. 2004). In vitro culture of $F$. psychrophilum can be difficult, and the media currently used is not optimal (Cepeda et al. 2004). Numerous attempts have been made to enhance bacterial growth in vitro (Daskalov et al. 1999, Michel et al. 1999, Cepeda et al. 2004); however, available media does not accurately reflect the environment to which F. psychrophilum is exposed in vivo. An analysis of specific protein changes following growth of $F$. psychrophilum in vivo and in iron-limited conditions may identify virulence factors and provide targets for vaccine development. The objective of the current study was to identify proteins of $F$. psychrophilum that increase or decrease in spot intensity (as assessed by 2D polyacrylamide gel electrophoresis [2D-PAGE]) following growth in vivo and in vitro under iron-limited conditions.

\section{MATERIALS AND METHODS}

Fish and rearing conditions. Fifteen rainbow trout with a mean weight of $150 \mathrm{~g}$ were obtained from the Aquaculture Research Institute (University of Idaho, Moscow). Prior to implantation, fish were acclimated for $1 \mathrm{wk}$ in a $190 \mathrm{l}$ tank supplied with de-chlorinated municipal water at $15^{\circ} \mathrm{C}$. Following implantation, fish were held in a $190 \mathrm{l}$ tank supplied with $15^{\circ} \mathrm{C}$ water. The fish were not fed during the trial. All procedures utilizing fish were approved by the University of Idaho Animal Care and Use Committee (Protocol \# 2006-31).

Bacterial culture. A previously frozen glycerol stock of a virulent strain of Flavobacterium psychrophilum, CSF-259-93 (Sudheesh et al. 2007), was plated for isolation on tryptone yeast extract salts (TYES; $0.4 \%$ tryptone, $0.04 \%$ yeast extract, $0.05 \% \mathrm{MgSO}_{4}, 0.05 \%$ $\mathrm{CaCl}_{2}, \mathrm{pH}$ 7.2) agar (Holt et al. 1993) and incubated at $15^{\circ} \mathrm{C}$ for $4 \mathrm{~d}$. Several colonies were transferred to $20 \mathrm{ml}$ TYES broth and incubated at $15^{\circ} \mathrm{C}$ for $72 \mathrm{~h}$. The $72 \mathrm{~h}$ cultures were used in the following growth conditions.

Growth in iron-limited conditions: A trial experiment was implemented to determine the optimal concentration of the iron chelator 2,2-dipyridyl (DPD; 
Sigma-Aldrich) to obtain inhibited growth of Flavobacterium psychrophilum. Duplicate culture tubes of $20 \mathrm{ml}$ TYES broth containing 0, 50, 75, and $100 \mu \mathrm{M}$ DPD were inoculated with $50 \mu \mathrm{l}$ of a $72 \mathrm{~h}$ culture of F. psychrophilum and incubated statically at $15^{\circ} \mathrm{C}$. Static growth conditions were used due to the tendency of this strain to auto-agglutinate when cultured on an orbital shaker. The growth was monitored daily by measuring the optical density at $525 \mathrm{~nm}$.

Flavobacterium psychrophilum was cultured in TYES broth with or without $50 \mu \mathrm{M}$ DPD to obtain cells for proteomic analyses. Two milliliters of a $72 \mathrm{~h}$ culture were inoculated into $200 \mathrm{ml}$ TYES broth with or without $50 \mu \mathrm{M}$ DPD and incubated statically at $15^{\circ} \mathrm{C}$ for $72 \mathrm{~h}$. Cells were harvested by centrifugation at $4300 \times g$ for $15 \mathrm{~min}$ at $4^{\circ} \mathrm{C}$ and washed twice with sterile phosphatebuffered saline (PBS; $137 \mathrm{mM} \mathrm{NaCl}, 2.7 \mathrm{mM} \mathrm{KCl}$, $4.3 \mathrm{mM} \mathrm{Na}_{2} \mathrm{HPO}_{4} \cdot 7 \mathrm{H}_{2} \mathrm{O}, 1.4 \mathrm{mM} \mathrm{KH}_{2} \mathrm{PO}_{4}, \mathrm{pH}$ 7.2).

Growth in vivo: A $72 \mathrm{~h}$ culture of Flavobacterium psychrophilum (2 ml) was inoculated into $200 \mathrm{ml}$ TYES broth and incubated at $15^{\circ} \mathrm{C}$ for $72 \mathrm{~h}$. Cells were harvested by centrifugation at $4300 \times g$ for $15 \mathrm{~min}$ at $4^{\circ} \mathrm{C}$, washed twice with sterile PBS, and resuspended to an optical density of 0.5 at $525 \mathrm{~nm}$ in PBS.

Dialysis tubing chambers $(\mathrm{n}=30)$, with a molecular weight cutoff of $12 \mathrm{kDa}$, were prepared as described by Colquhoun \& Sorum (1998) and each chamber was inoculated with $1 \mathrm{ml}$ of the resuspended Flavobacterium psychrophilum. Fifteen rainbow trout were implanted (peritoneal cavity) with 1 dialysis tubing chamber each as described by Colquhoun \& Sorum (1998), with the exception that $90 \mathrm{mg} \mathrm{l}^{-1}$ tricaine methanesulfonate (MS-222; Argent Chemicals) was used for anesthetization and gill flushing. Following surgery, fish were immediately returned to the culture tank and monitored for recovery. Control dialysis tubing chambers $(n=15)$ were inoculated as described at the beginning of this paragraph and incubated in $500 \mathrm{ml}$ TYES broth at $15^{\circ} \mathrm{C}$.

Harvest and quantification of bacteria from dialysis tubing chambers. At 2, 4, 6, 8, and 10 d post-implantation, 3 fish were killed with an overdose of MS-222 $\left(250 \mathrm{mg} \mathrm{l}^{-1}\right)$, and the dialysis tubing chambers were removed. Additionally, 3 control chambers were removed from TYES broth at each sampling time. The external surface of each chamber was washed with sterile PBS, and the contents were extracted using a sterile 21-gauge needle and placed into sterile $1.5 \mathrm{ml}$ microcentrifuge tubes. Twenty microliters of each culture were streaked for isolation onto tryptic soy agar and TYES plates and incubated at $15^{\circ} \mathrm{C}$ for $72 \mathrm{~h}$ to check for bacterial contamination. The number of colony-forming units (CFUs) of Flavobacterium psychrophilum $\mathrm{ml}^{-1}$ of each culture was determined by plating 10-fold serial dilutions on TYES agar plates.
The remaining culture was centrifuged at $5000 \times g$ for $20 \mathrm{~min}$ at $4^{\circ} \mathrm{C}$, the supernatant was removed, and bacterial pellets were stored at $-20^{\circ} \mathrm{C}$.

Preparation of whole-cell lysates. Whole-cell lysates of Flavobacterium psychrophilum cultured in TYES and TYES with $50 \mu \mathrm{M}$ DPD were prepared by resuspending $100 \mathrm{mg}$ (wet wt) of cells into $800 \mu \mathrm{l}$ deionized water containing $0.1 \mathrm{mM}$ phenylmethanesulfonyl fluoride (PMSF, Sigma-Aldrich). The cell suspensions were sonicated on ice 8 times for $30 \mathrm{~s}$ each at $20 \%$ amplitude (Model 500 Sonic Dismembrator, Fisher Scientific). The suspensions were cooled on ice for 2 min between each 30 s sonication step. The lysates were centrifuged at $16000 \times g$ for $30 \mathrm{~min}$ at $4^{\circ} \mathrm{C}$, and then the supernatants were removed and frozen at $-80^{\circ} \mathrm{C}$.

For each sampling period, the Flavobacterium psychrophilum cell pellets obtained from triplicate dialysis tubing chambers incubated in vivo or in vitro were combined according to treatment and resuspended into $200 \mu$ deionized water containing $0.1 \mathrm{mM}$ PMSF. Whole-cell lysates were prepared by sonicating the resuspended bacteria for $8 \mathrm{~min}$ in a cup sonicator using chilled deionized water (Sonicator Ultrasonic Processor $\mathrm{XL}$, Misonix). Following sonication, the lysates were centrifuged at $16000 \times g$ for $30 \mathrm{~min}$ at $4^{\circ} \mathrm{C}$, and then supernatants were removed and frozen at $-80^{\circ} \mathrm{C}$. The protein concentration of each lysate was determined using a Micro BCA Protein Assay (Pierce) according to the manufacturer's directions.

2D-PAGE. Whole-cell lysate proteins were diluted to a concentration of $0.48 \mu \mathrm{g} \mathrm{ll}^{-1}$ in rehydration buffer containing $8 \mathrm{M}$ urea, $50 \mathrm{mM}$ dithiothreitol (DTT), $4 \%$ 3-[(3-cholamidopropyl)dimethylammonia]-1-propanesulfonate, and 0.25\% Bio-Lyte 3/10 ampholyte (Bio-Rad). Protein samples were vortexed for $1 \mathrm{~min}$, incubated at room temperature for $10 \mathrm{~min}$, then centrifuged at $16000 \times g$ for $10 \mathrm{~min}$ at room temperature. Immobilized pH gradient (IPG) strips ( $7 \mathrm{~cm}, \mathrm{pH} 3$ to 10; Bio-Rad) were passively rehydrated with $60 \mu \mathrm{g}$ protein $(125 \mu \mathrm{l}$ strip $^{-1}$ ) for $1 \mathrm{~h}$, covered with $2 \mathrm{ml}$ mineral oil, and then rehydrated overnight at room temperature. Firstdimension isoelectric focusing was performed using a PROTEAN IEF Cell (Bio-Rad). IPG strips were focused at $250 \mathrm{~V}$ for $15 \mathrm{~min}$, ramped up to $4000 \mathrm{~V}$ over $2 \mathrm{~h}$, held at $4000 \mathrm{~V}$ for 20000 volt hours (Vh), and then held at $500 \mathrm{~V}$ until frozen at $-80^{\circ} \mathrm{C}$. The total Vh applied to the IPG strips was approximately 25000 . Focused strips were thawed and equilibrated for $20 \mathrm{~min}$ in equilibration buffer (6 M urea, 2\% SDS, $0.375 \mathrm{M}$ Tris- $\mathrm{HCl}$ pH 8.8, 20\% glycerol) containing $130 \mathrm{mM}$ DTT and then equilibrated for an additional $20 \mathrm{~min}$ in equilibration buffer containing $135 \mathrm{mM}$ iodoacetamide. Seconddimension separation of equilibrated IPG strips was performed in 10 to $20 \%$ linear gradient polyacrylamide gels (Bio-Rad) using a Mini-PROTEAN 3 electrophore- 
sis cell, and Precision Plus (Bio-Rad) protein standard plugs were included. Gels were electrophoresed using the standard Laemmli buffer system (Laemmli 1970) for $30 \mathrm{~min}$ at $5 \mathrm{~mA} \mathrm{gel}^{-1}$ and then at $12 \mathrm{~mA} \mathrm{gel}^{-1}$ until the dye front migrated out of the gels.

To determine the reproducibility of this method, whole-cell lysates from 2 biological replicates of Flavobacterium psychrophilum cultured in TYES broth were analyzed. Duplicate IPG strips were focused with proteins from each biological replicate and 2D-PAGE was performed as described in the previous paragraph. Gels were analyzed as described below ('Image analysis of 2D-PAGE gels') and a scatter plot and regression line was generated to determine the degree of similarity between the gels obtained from both biological replicates. A correlation coefficient of 0.93 was obtained, demonstrating the reproducibility of the method (data not shown).

Image analysis of 2D-PAGE gels. Gels were stained with SYPRO Ruby (Bio-Rad) according to the manufacturer's directions, digitally imaged using a FLUOR-S MultiImager (Bio-Rad), and analyzed with PDQuest version 8.0.1 (Bio-Rad). Automated spot detection and matching were used followed by a manual inspection for accuracy, and all gels were normalized using the local regression model. For each comparison (normal TYES versus iron-limited TYES and in vivo versus in vitro at 2, 4, 6, 8, and $10 \mathrm{~d}$ ), 4 gels were analyzed representing 1 biological replicate and duplicate gels for each culture condition. Gels were analyzed for qualitative differences (protein spots unique to each culture condition) and quantitative differences (protein spot intensity changes $\geq 2.0$-fold). For each protein identified by liquid chromatography-mass spectrometry/ mass spectrometry (LC-MS/MS), the spot intensities at each sampling time were quantified and reported as the ratio of spot intensity of in vivo culture to in vitro culture to determine if the spot intensities changed over the course of the $10 \mathrm{~d}$ experiment.

Identification of differentially expressed proteins. Proteins of interest were excised from SYPRO Rubystained gels, placed in $5 \%$ acetic acid, and submitted to the Proteomics Core Facility at Michigan State University (East Lansing) for LC-MS/MS analysis. Proteins within each excised gel piece were subjected to in-gel tryptic digestion (Shevchenko et al. 1996, Jensen et al. 1999). The extracted peptides were automatically injected by a Michrom Paradigm Endurance Bio-Cool Autosampler onto a Michrom Paradigm Platinum Peptide Nanotrap $(\mathrm{C} 18,0.15 \times 50 \mathrm{~mm})$ and washed for $5 \mathrm{~min}$. The bound peptides were then eluted onto a $10 \mathrm{~cm} \times 75 \mu \mathrm{m}$ New Objective Picofrit column packed with Michrom Magic C18 AQ packing material. Peptides were eluted from this column over 30 min with a gradient of $5 \%$ B to $90 \%$ B, with constant $10 \%$ C in
24 min using a Michrom Paradigm MDLC (Buffer A = $100 \%$ water; Buffer B $=100 \%$ acetonitrile; Buffer C $=$ $1 \%$ formic acid) into a ThermoFisher LTQ linear ion trap mass spectrometer at a flow rate of $250 \mathrm{nl} \mathrm{min}{ }^{-1}$. The top 5 ions in each survey scan were subjected to data-dependent zoom scans followed by low-energy collision-induced dissociation and the resulting MS/MS spectra were converted to peak lists using BioWorks Browser Version 3.2 (ThermoFisher). The peak lists were searched against the Flavobacterium psychrophilum (ATCC 49511) genome (Duchaud et al. 2007) (EMBL database accession no. AM398681) using the Mascot searching algorithm Version 2.2 (Matrix Science). For all searches, peptide tolerance was set to $200 \mathrm{ppm}$, fragment tolerance was $0.8 \mathrm{Da}, 2$ tryptic missed cleavages were allowed, and the carbamidomethyl (C) and oxidation (M) peptide modifications were considered. All spectral assignments were then validated using Scaffold Version Scaffold-01_07_00 (Proteome Software). Identifications were considered positive if 2 or more peptides from the same protein were identified and the confidence level of the Scaffold analysis was $>95 \%$. Estimation of the theoretical molecular mass $\left(\mathrm{M}_{\mathrm{r}}\right)$ and isoelectric points (pI) of the proteins identified were determined using the Compute $\mathrm{pI} / \mathrm{Mw}$ tool (http://ca.expasy.org/tools/pi_tool.html).

\section{RESULTS}

\section{Growth in iron-limited media}

Growth curves of Flavobacterium psychrophilum (CSF-259-93) were determined in TYES broth containing $0,50,75$, and $100 \mu \mathrm{M}$ of DPD at $15^{\circ} \mathrm{C}$ (Fig. 1). There was a dose response between the concentration of DPD and bacterial growth. Growth was partially inhibited at $50 \mu \mathrm{M}$ DPD and almost completely inhibited at $100 \mu \mathrm{M}$ DPD (Fig. 1). A DPD concentration of $50 \mu \mathrm{M}$ was chosen for the subsequent growth of $F$. psychrophilum in iron-limited conditions to identify proteins with different spot intensities.

\section{In vivo growth in dialysis tubing chambers}

Pure Flavobacterium psychrophilum cultures were obtained from all dialysis tubing chambers with the exception of 1 chamber recovered from a fish on Day 8 , and this culture was removed from the analysis. The number of CFUs ml ${ }^{-1}$ was determined for F. psychrophilum cultured in vivo and in vitro in dialysis tubing chambers at each sampling period (Fig. 2). F. psychrophilum cultured in vivo exhibited an initial decrease in viable cells. Growth then increased rapidly from 


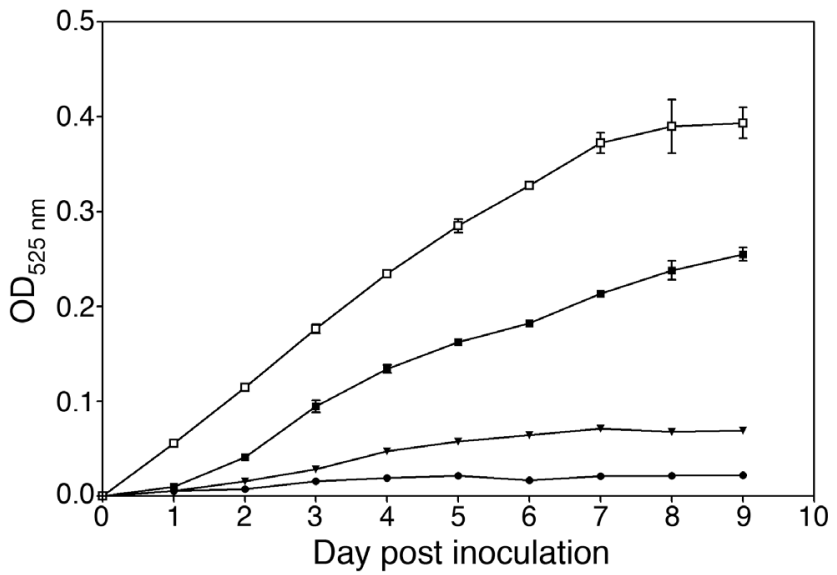

Fig. 1. Flavobacterium psychrophilum. Growth curves of F. psychrophilum (CSF-259-93) cultured in tryptone yeast extract salts broth containing $0($ (), $50(\boldsymbol{\bullet}), 75(\mathbf{v})$, or $100(\bullet) \mu \mathrm{M}$ 2,2-dipyridyl (DPD). Duplicate cultures were grown under each condition at $15^{\circ} \mathrm{C}$ and growth was monitored daily by determining the optical density (OD) at $525 \mathrm{~nm}$. Error bars indicate $\mathrm{SD}$

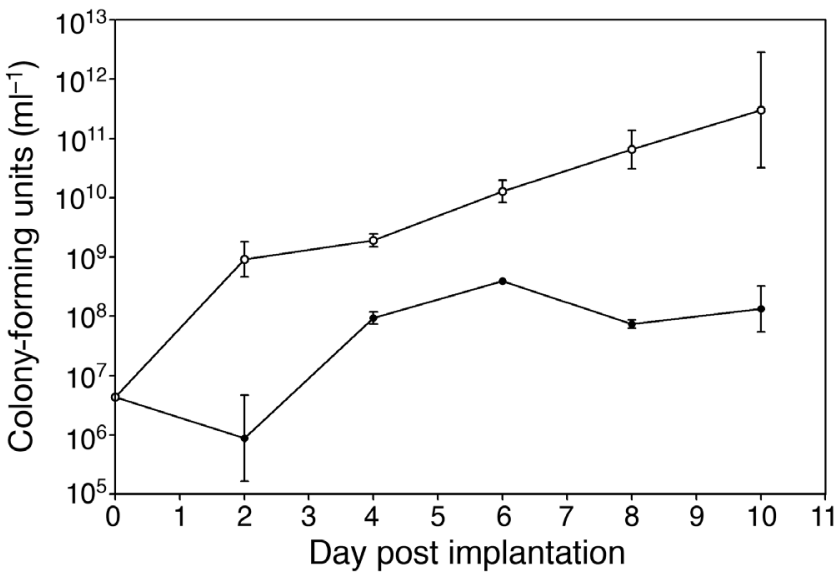

Fig. 2. Flavobacterium psychrophilum. Growth curves of F. psychrophilum (CSF-259-93) cultured in dialysis tubing chambers in vitro $(\circ)$ or in vivo $(\bullet)$. Triplicate cultures were removed at each sampling period, and the number of colonyforming units $\mathrm{ml}^{-1}$ was determined by plating serial dilutions onto tryptone yeast extract salts agar plates. Error bars indicate SD
Days 2 to 6 , and then cell numbers decreased slightly through $10 \mathrm{~d}$ postimplantation. F. psychrophilum cultured in vitro exhibited linear growth throughout the trial (Fig. 2).

\section{D-PAGE profile following iron- limited conditions}

Whole-cell lysate proteins of Flavobacterium psychrophilum cultured in TYES broth and iron-limited TYES broth were separated by 2D-PAGE, stained, and analyzed to identify proteins with different spot intensities (Fig. 3). Thirty-two proteins exhibited a

Fig. 3. Flavobacterium psychrophilum. 2D polyacrylamide gel electrophoresis analysis of whole-cell lysate proteins of $F$. psychrophilum cultured in (A) tryptone yeast extract salts (TYES) broth or (B) iron-limited TYES broth. Proteins were visualized by SYPRO Ruby staining. Proteins with increased spot intensities for each growth condition are circled, and protein spot numbers correspond to proteins identified by liquid chromatography-mass spectrometry/mass spectrometry (see Table 1). Firstdimension separation was performed using immobilized $\mathrm{pH}$ gradient strips with a $\mathrm{pH}$ range of 3 to 10, and second-dimension molecular mass markers $(\mathrm{kDa})$ are indicated to the left of each gel

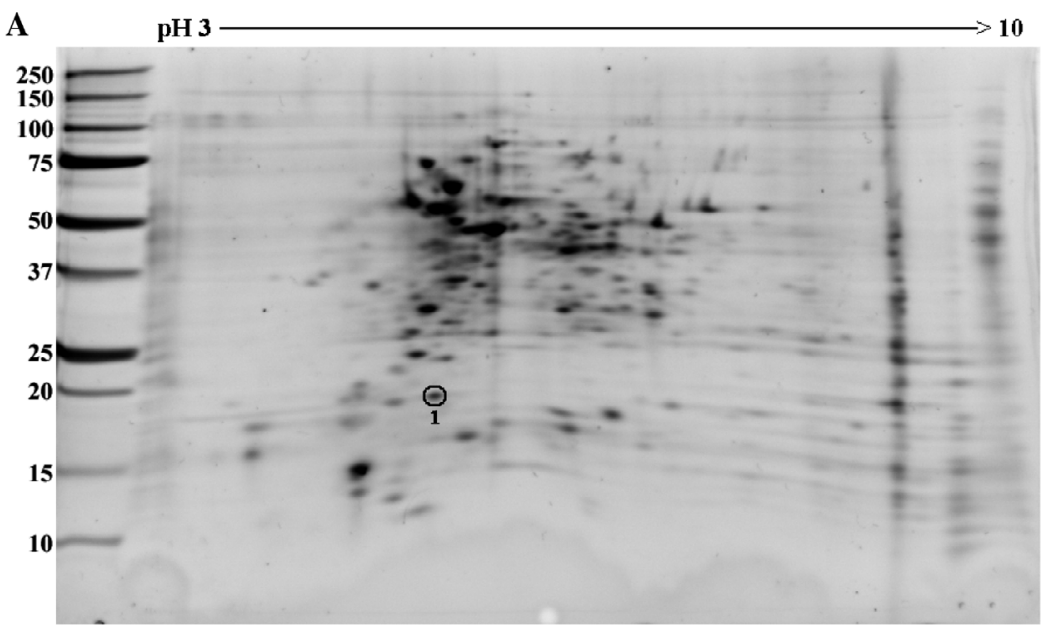

B pH 3 $>10$

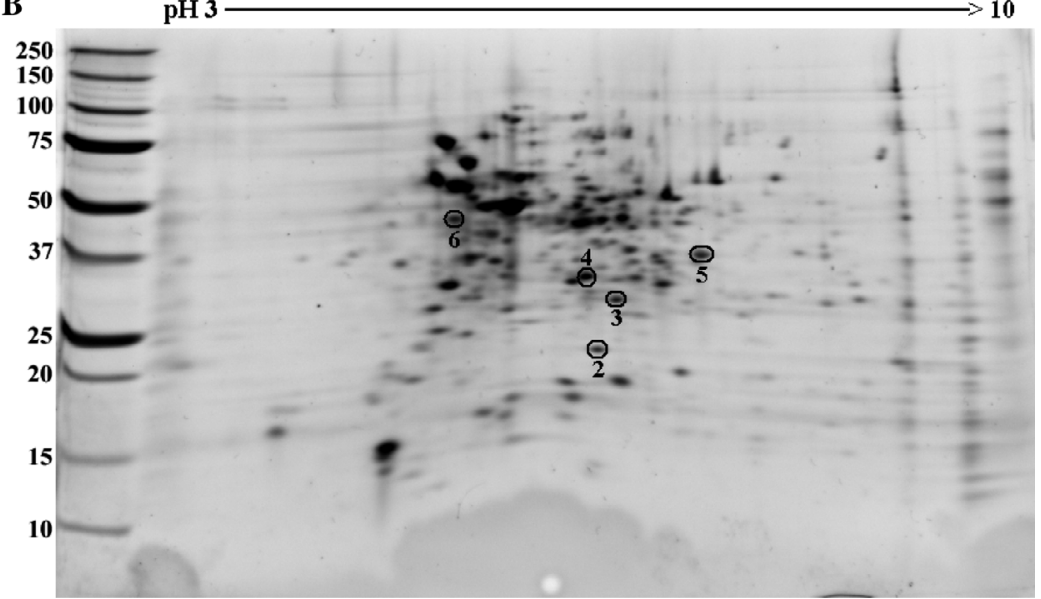


$\geq 2.0$-fold change in spot intensity, 15 or 17 of which were increased or decreased in iron-limited media, respectively. Additionally, 13 proteins were identified as unique to iron-limited media and 8 proteins were unique to normal TYES media. Five proteins exhibiting increased spot intensities following culture in ironlimited media were selected for identification (Fig. 3B). Two of these proteins were identified as proteins with unknown function, whereas the other 3 were identified as universal stress protein UspA, 3-oxoacyl-[acylcarrier-protein]-reductase, and gliding motility protein GldN (Table 1). One protein with decreased spot intensity in iron-limited media (Fig. 3A) was selected and identified as ferritin FtnA (Table 1).

\section{D-PAGE profile following in vivo growth}

A comparative analysis of Flavobacterium psychrophilum proteins following in vivo and in vitro growth in dialysis tubing chambers revealed numerous differences, and this was best exemplified at $8 \mathrm{~d}$ postimplantation (Fig. 4). Fifty-two proteins exhibited a $\geq 2.0$-fold change in spot intensity, 27 or 25 of which were increased or decreased following in vivo growth, respectively. Additionally, 31 proteins were identified as unique to bacteria cultured in vivo and 12 proteins were unique to in vitro cultured cells. Eighteen proteins exhibiting increased spot intensities in vivo were selected for identification (Fig. 4, Table 1). Single unique proteins were positively identified for 16 of these and included several chaperone and stress proteins, gliding motility protein GldN, outer membrane protein $\mathrm{OmpH}$, probable outer membrane protein (OmpA family), probable aminopeptidase precursor, probable lipoprotein precursor, 3-oxoacyl-[acyl-carrier-protein]reductase, and 5 proteins with unknown function (Fig. 4, Table 1). For one spot (Protein spot no. 10), 2 proteins were identified (FP1486, protein of unknown function; FP0770, probable acetyl-CoA acetyltransferase), and for another spot (Protein spot no. 17) a single protein sequence was identified but 2 identical genes (FP0321 and FP1169, probable outer membrane protein OmpA family) were present in the genome. Two proteins exhibiting decreased spot intensities in vivo were selected and identified as ferritin FtnA and

Table 1. Flavobacterium psychrophilum. Proteins of F. psychrophilum identified by liquid chromatography-mass spectrometry/mass spectrometry. Protein spot numbers refer to proteins in Figs. $3 \& 4 . \mathrm{M}_{\mathrm{r}}$ : molecular mass; pI: isoelectric point

\begin{tabular}{|c|c|c|c|c|c|c|}
\hline $\begin{array}{l}\text { Spot } \\
\text { no. }\end{array}$ & Identified protein & $\begin{array}{l}\text { NCBI accession } \\
\text { no. (locus tag) }\end{array}$ & $\begin{array}{l}\text { Theoretical } \\
\mathrm{M}_{\mathrm{r}}(\mathrm{kDa}) / \mathrm{pI}\end{array}$ & $\begin{array}{l}\text { No. peptides } \\
\text { matched }\end{array}$ & $\begin{array}{c}\text { Sequence } \\
\text { coverage }(\%)\end{array}$ & $\begin{array}{c}\text { Mascot } \\
\text { score }\end{array}$ \\
\hline 1 & Ferritin FtnA & FP1782 & $20.3 / 4.94$ & 9 & 55 & 519 \\
\hline 2 & Protein of unknown function & FP1493 & $22.7 / 8.61$ & 7 & 54 & 538 \\
\hline 3 & 3-oxoacyl-[acyl-carrier-protein]-reductase & FP0964 & $26.3 / 5.95$ & 3 & 15 & 267 \\
\hline 4 & Universal stress protein UspA & FP0467 & $30.5 / 5.73$ & 3 & 17 & 326 \\
\hline 5 & Protein of unknown function & FP1496 & $36.2 / 8.77$ & 18 & 60 & 1213 \\
\hline 6 & Gliding motility protein GldN & FP1970 & $39.1 / 5.82$ & 7 & 28 & 595 \\
\hline 7 & Probable lipoprotein precursor & FP2424 & $15.3 / 5.10$ & 3 & 37 & 216 \\
\hline 8 & Protein of unknown function & FP0012 & $16.1 / 7.83$ & 4 & 59 & 366 \\
\hline 9 & Outer membrane protein $\mathrm{OmpH}$ & FP2098 & $18.7 / 8.58$ & 6 & 42 & 995 \\
\hline 10 & $\begin{array}{l}\text { Protein of unknown function } \\
\text { Probable acetyl-CoA acetyltransferase }\end{array}$ & $\begin{array}{l}\text { FP1486 } \\
\text { FP0770 }\end{array}$ & $\begin{array}{l}44.7 / 5.61 \\
40.8 / 5.39\end{array}$ & $\begin{array}{l}9 \\
4\end{array}$ & $\begin{array}{l}34 \\
17\end{array}$ & $\begin{array}{l}701 \\
465\end{array}$ \\
\hline 11 & Chaperone protein HtpG & FP1509 & $71.6 / 5.07$ & 16 & 26 & 1039 \\
\hline 12 & Probable lipoprotein of unknown function & FP0110 & $60.7 / 6.35$ & 6 & 16 & 444 \\
\hline 13 & $\begin{array}{l}\text { ATPase with chaperone activity } \\
\text { ATP-binding subunit ClpB }\end{array}$ & FP1765 & $96.9 / 5.33$ & 23 & 32 & 1927 \\
\hline 14 & Probable aminopeptidase precursor & FP1888 & $84.0 / 6.01$ & 8 & 15 & 620 \\
\hline 15 & Probable outer membrane protein, OmpA family & FP2411 & $69.9 / 6.6$ & 4 & 12 & 407 \\
\hline 16 & Probable outer membrane protein, OmpA family & FP2411 & $69.9 / 6.6$ & 20 & 35 & 1156 \\
\hline 17 & Probable outer membrane protein, OmpA family & $\begin{array}{l}\text { FP0321 } \\
\text { FP1169 }\end{array}$ & $72.5 / 6.52$ & 17 & 36 & 1552 \\
\hline 18 & Peptidyl-prolyl cis-trans isomerase precursor SurA & A FP1167 & $52.4 / 7.04$ & 8 & 20 & 726 \\
\hline 19 & Protein of unknown function & FP2205 & $63.3 / 8.78$ & 6 & 13 & 428 \\
\hline 20 & Outer membrane protein OmpA (P60) & FP0156 & $49.4 / 4.87$ & 6 & 19 & 602 \\
\hline
\end{tabular}


A

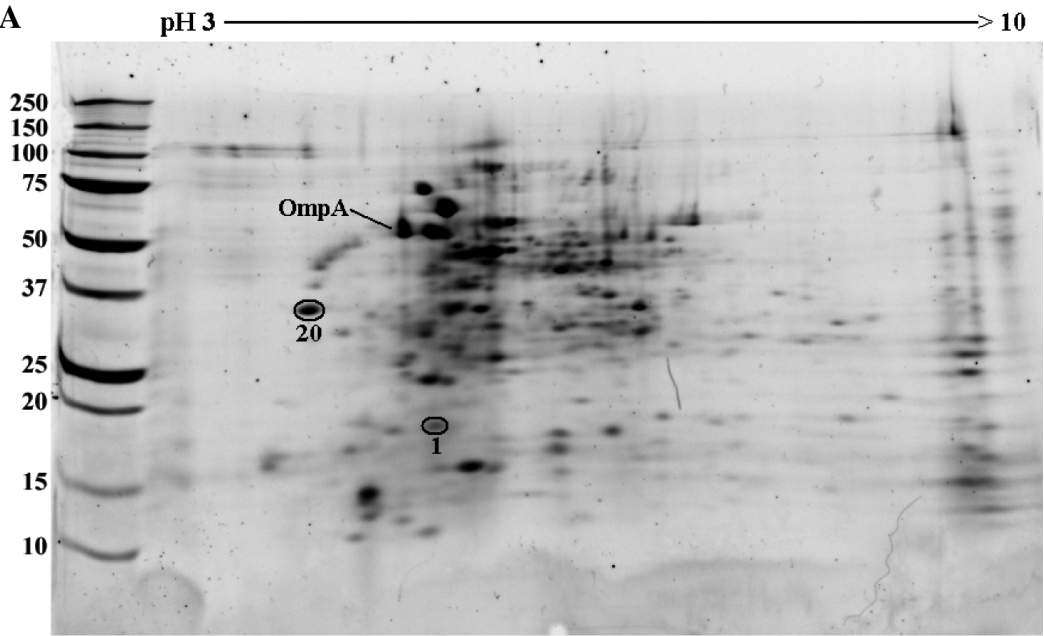

B

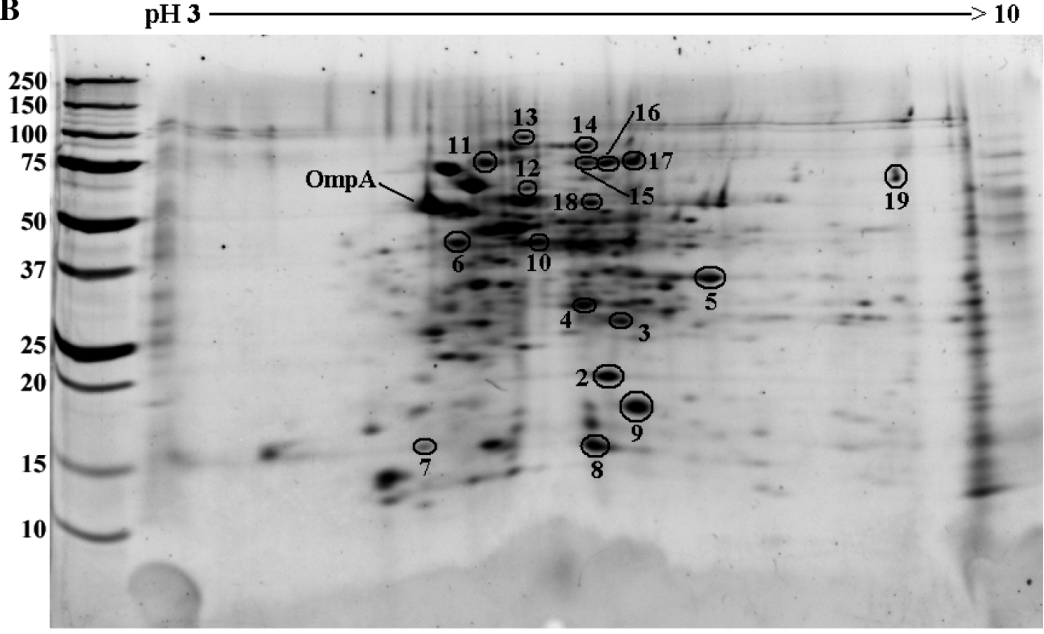

Fig. 4. Flavobacterium psychrophilum. 2D polyacrylamide gel electrophoresis analysis of whole-cell lysate proteins of $F$. psychrophilum cultured in dialysis tubing chambers (A) in vitro or (B) in vivo for $8 \mathrm{~d}$. Proteins were visualized by SYPRO Ruby staining. Proteins with increased spot intensities for each growth condition are circled, and protein spot numbers correspond to proteins identified by liquid chromatography-mass spectrometry/mass spectrometry (see Table 1). The protein spot labeled as OmpA (P60) was previously identified (LaFrentz 2007). First-dimension separation was performed using immobilized $\mathrm{pH}$ gradient strips with a $\mathrm{pH}$ range of 3 to 10 , and second-dimension molecular mass markers $(\mathrm{kDa})$ are indicated to the left of each gel

outer membrane protein OmpA (P60), respectively (Fig. 4, Table 1).

The ratio of spot intensities between in vivo and in vitro cultured Flavobacterium psychrophilum cells for each protein identified by LC-MS/MS was calculated to determine if there were trends over the course of the $10 \mathrm{~d}$ experiment (Table 2). Protein spot nos. 2, 5, 8, 13, and 19 were consistently present at higher spot intensities in vivo at each sampling time. Protein spot nos. 9, 10, and 11 exhibited a general trend of increasing spot intensities in vivo over the course of the experiment. Protein spot nos. 3, 6, 12, 15, 16, and 18 exhibited a general trend of increasing spot intensities in vivo from Days 2 to 8, and then decreased spot intensities in vivo on Day 10. Protein spot no. 1 was consistently present at lower spot intensities in vivo from Days 2 to 6 and was absent in vivo on Days 8 and 10. At each sampling time, Protein spot no. 7 was only present in in vivo cultured cells, and Protein spot no. 20 was only present in in vitro cultured cells. There were no major differences in the protein spot intensities of F. psychrophilum cultured in vitro in the dialysis tubing chambers over the $10 \mathrm{~d}$ experiment (data not shown).

\section{DISCUSSION}

Stress resistance is an important mechanism for survival in the host environment (Vorob'eva 2004). Bacteria produce a number of heat shock and chaperone proteins that are important for this adaptation (Vorob'eva 2004). Similarly, several chaperone and stress proteins of Flavobacterium psychrophilum exhibited increased spot intensities following in vivo growth. These included the chaperone protein HtpG, peptidylprolyl cis-trans isomerase precursor SurA, ATPase with chaperone activity ClpB, and universal stress protein UspA. Additionally, a protein identified as one with unknown function (Protein spot no. 19; Table 1) contained a tetratricopeptide repeat motif that is common in chaperone proteins or proteins involved in protein-protein interactions (Blatch \& Lassle 1999). This suggests that these proteins may be important for in vivo survival and pathogenesis of F. psychrophilum, and there is evidence for this based on homologous proteins in other pathogenic bacterial species.

The HtpG chaperone protein plays an important role in providing bacterial cells with protection from oxidative and temperature stress (Tanaka \& Nakamoto 1999, Okano et al. 2006), and the production of this protein in Porphyromonas gingivalis is upregulated following contact with human epithelial cells (Hosogi \& Duncan 2005). Further, this protein may play an important role in the pathogenesis of Francisella tularensis because an htpG mutant was highly attenuated and unable to sustain intracellular growth (Weiss et al. 2007). 
Table 2. Flavobacterium psychrophilum. Quantification of F. psychrophilum proteins identified by 2D polyacrylamide gel electrophoresis from bacteria cultured in vivo for $10 \mathrm{~d}$. Protein spot intensity ratio: in vivo to in vitro cultured cells. vit: protein absent from in vivo cultured cells; viv: protein only present for in vivo cultured cells; neith: protein absent from both growth conditions

\begin{tabular}{|c|c|c|c|c|c|c|}
\hline \multirow{2}{*}{$\begin{array}{l}\text { Spot } \\
\text { no. }\end{array}$} & \multirow{2}{*}{ Identified protein } & \multicolumn{5}{|c|}{ Protein spot intensity ratio } \\
\hline & & Day 2 & Day 4 & Day 6 & Day 8 & Day 10 \\
\hline 1 & Ferritin FtnA & 0.24 & 0.38 & 0.19 & vit & vit \\
\hline 2 & Protein of unknown function & viv & 3.05 & 3.22 & 2.53 & 8.56 \\
\hline 3 & 3-oxoacyl-[acyl-carrier-protein]-reductase & 0.82 & 1.12 & 1.72 & 4.2 & 1.48 \\
\hline 4 & Universal stress protein UspA & 2.08 & 1.72 & 1.55 & 2.43 & 0.67 \\
\hline 5 & Protein of unknown function & 6.84 & 5.82 & 5.03 & 8.27 & 5.72 \\
\hline 6 & Gliding motility protein GldN & 0.67 & 0.98 & 1.74 & 2.85 & 1.29 \\
\hline 7 & Probable lipoprotein precursor & viv & viv & viv & viv & viv \\
\hline 8 & Protein of unknown function & 2.99 & 2.67 & 1.95 & 2.12 & 2.54 \\
\hline 9 & Outer membrane protein $\mathrm{OmpH}$ & 1.54 & 1.7 & 1.68 & 1.95 & 3.18 \\
\hline 10 & $\begin{array}{l}\text { Protein of unknown function } \\
\text { Probable acetyl-CoA acetyltransferase }\end{array}$ & neith & neith & 0.99 & viv & 2.04 \\
\hline 11 & Chaperone protein HtpG & neith & 1.67 & 1.33 & 2.74 & 2.46 \\
\hline 12 & Probable lipoprotein of unknown function & 1.03 & 0.51 & 3.4 & viv & 1.45 \\
\hline 13 & $\begin{array}{l}\text { ATPase with chaperone activity } \\
\text { ATP-binding subunit ClpB }\end{array}$ & 2.03 & viv & 1.86 & viv & 5.17 \\
\hline 14 & Probable aminopeptidase precursor & viv & 3.0 & 1.26 & 3.52 & 1.53 \\
\hline 15 & Probable outer membrane protein, OmpA family & viv & viv & 2.13 & 4.6 & 1.38 \\
\hline 16 & Probable outer membrane protein, OmpA family & 0.91 & 1.21 & 1.64 & 3.18 & 1.82 \\
\hline 17 & Probable outer membrane protein, OmpA family & 1.35 & 1.38 & 1.3 & 1.68 & 1.76 \\
\hline 18 & Peptidyl-prolyl cis-trans isomerase precursor SurA & 1.5 & 1.5 & 1.97 & 1.57 & 1.17 \\
\hline 19 & Protein of unknown function & viv & viv & 2.37 & 6.10 & 2.12 \\
\hline 20 & Outer membrane protein OmpA (P60) & vit & vit & vit & vit & vit \\
\hline
\end{tabular}

A primary role of the SurA chaperone protein is to assist in the folding of outer membrane proteins (Lazar \& Kolter 1996). SurA interacts with proteins involved in pilus production and adhesion (Justice et al. 2005). Mutations in surA have been associated with attenuation in Salmonella enterica and Klebsiella pneumoniae (Sydenham et al. 2000, Struve et al. 2003). Interestingly, the SurA protein of Brucella abortus has been identified as a protective antigen (Delpino et al. 2007). Immunization of mice with recombinant SurA from $B$. abortus conferred a protective immune response as determined by a significant reduction in the number of CFUs in the spleen (Delpino et al. 2007).

ClpB protein is a chaperone that belongs to the Clp ATPase family, and it is involved in protein disaggregation (Squires \& Squires 1992) and stress responses (Squires \& Squires 1992, Ekaza et al. 2001). Research suggests that this protein may be involved in the virulence of bacterial pathogens (Chastanet et al. 2004, Yuan et al. 2007). The ClpB protein of Francisella tularensis is immunogenic (Havlasova et al. 2005), and similarly the ClpB protein of Flavobacterium psychrophilum is immunogenic (LaFrentz 2007).

The expression of the gene encoding the stress protein UspA increases following numerous stressors
(Nystrom \& Neidhardt 1992) and during in vivo growth (Twine et al. 2006, Hughes et al. 2007). Additionally, there is evidence that the UspA protein of Salmonella typhimurium is involved in pathogenesis because a mutant strain with a defective uspA gene was attenuated in mice when administered orally at low doses (Liu et al. 2007). Research is needed to further define the role of these chaperone and stress proteins in the pathogenesis of Flavobacterium psychrophilum and their potential as vaccine candidate antigens.

The Flavobacterium psychrophilum gliding motility protein GldN exhibited increased spot intensity during growth in vivo and in iron-limited media. The role of gliding motility in the pathogenesis of F. psychrophilum is not known, but in general, motility is assumed to be an important factor in host-pathogen interactions (Ottemann \& Miller 1997). Martinez et al. (2004) suggested that F. psychrophilum uses a combination of proteolytic activity and gliding motility as a mechanism to gain entry into host tissues. The GldN of $F$. johnsoniae has been characterized and is involved in motility and chitin utilization (Braun et al. 2005). The upregulation of the GldN protein of F. psychrophilum in vivo suggests that it may play a role in pathogenesis, and host-related nutrients appear to turn on the associ- 
ated gene. Further, this protein is immunogenic in rainbow trout, exhibiting enhanced protection against experimental F. psychrophilum challenge (LaFrentz 2007), and may therefore be a promising vaccine candidate antigen.

The outer membrane protein OmpH of Flavobacterium psychrophilum has been extensively characterized (Massias et al. 2004, Dumetz et al. 2006) and is immunogenic (Dumetz et al. 2006, 2008). Initial studies demonstrated that this protein is continuously produced and the production is not affected by temperature and aeration (Massias et al. 2004). In the present study, an increased spot intensity of OmpH was observed in vivo suggesting that certain environmental factors stimulate this response. Antibodies specific for the $\mathrm{OmpH}$ protein were demonstrated to have bacteriostatic and bacteriocidal activities, and immunization of rainbow trout with semi-purified OmpH stimulated protective immunity against experimental F. psychrophilum challenge (Dumetz et al. 2006). Brown et al. (1988) suggested that vaccines based on surface proteins will only be successful if the proteins are produced in vivo; thus, the present results provide further support for the use of the OmpH protein of F. psychrophilum as a vaccine candidate.

Two probable outer membrane proteins of Flavobacterium psychrophilum with similarity to the OmpA family were identified with increased spot intensity in vivo. Protein spot nos. 15 and 16 were both identified as a probable outer membrane protein, OmpA family (FP2411), which suggests this protein is modified posttranslation because they differ in pI, but have the same molecular mass. Protein spot no. 17 was identified as an OmpA-family outer membrane protein. Interestingly, there are 2 identical copies of this gene in the F. psychrophilum genome (FP0321 and FP1169). OmpA and OmpA-like proteins are well documented as bacterial virulence factors (Smith et al. 2007), and some studies have suggested roles in adhesion (Dabo et al. 2003, Serino et al. 2007). It is possible that these proteins play a similar role in the pathogenesis of F. psychrophilum. Considering the surface exposure and increased spot intensities in vivo, these proteins are promising candidates for further investigation. OmpA and OmpA-like proteins have been identified as vaccine candidate antigens (Ochoa-Reparaz et al. 2004, Kurupati et al. 2006) and appear protective in other systems (Ross et al. 2004).

Several proteins that exhibited increased spot intensity in vivo were positively identified, but these proteins did not exhibit similarity to any known proteins (Table 1). Two of these proteins are of interest for vaccine development. These include the probable lipoprotein of unknown function (Protein spot no. 12) and a protein with unknown function (Protein spot no. 10). These proteins were recently identified in an outer membrane extraction of Flavobacterium psychrophilum and were demonstrated to be immunogenic by Western blot analysis with CWD-convalescent rainbow trout serum (Dumetz et al. 2008). Although the functions of these proteins are not known, they may be good candidates for vaccine development due to their potential surface exposure, immunogenicity, and increased spot intensity in vivo.

Two proteins exhibited decreased spot intensity in vivo. One of these was identified as ferritin FtnA, and it was also downregulated in iron-limited growth conditions. FtnA is an iron-storage protein, and it functions to bind intracellular iron that can be toxic and stores iron for use if needed in an iron-limited environment (Andrews et al. 2003). The results of the present study suggest that the FtnA of Flavobacterium psychrophilum functions in a similar manner. The spot intensity of this protein was increased when F. psychrophilum was cultured in TYES media, presumably for binding excess iron to avoid toxicity and to serve as a reserve for future use. However, culture of the bacterium in ironlimited and in vivo growth conditions resulted in decreased spot intensity of this protein, presumably because there was no need to store iron in these conditions. The mechanism by which F. psychrophilum regulates its iron metabolism is not known, but it may be mediated by the ferric-uptake regulator (Fur) protein as in Escherichia coli (Andrews et al. 2003), and there is a putative Fur homologue (FP1903) present in the F. psychrophilum genome.

OmpA (P60) also exhibited decreased spot intensity in vivo. This was an interesting identification because the approximate experimental molecular mass ( 35 kDa) was much lower than expected for this protein (Table 1). Previous research in our laboratory has identified another protein spot at $\sim 58 \mathrm{kDa}$ as OmpA (P60) (Fig. 4), which was immunogenic and exhibited experimental values that are closer to the theoretical molecular mass and pI of the protein (LaFrentz 2007). Similarly, Dumetz et al. (2008) identified multiple protein spots with approximate molecular masses of $<30 \mathrm{kDa}$ as OmpA (P60), and they suggested that these represented degraded OmpA (P60) products from sample preparation. In the present study, this seems unlikely because the wholecell lysates were prepared identically for Flavobacterium psychrophilum cultured in vivo and in vitro. Using the same sample preparation methods, the $\sim 35 \mathrm{kDa}$ OmpA (P60) protein was consistently absent from F. psychrophilum cultured in vivo, and the $\sim 58 \mathrm{kDa}$ OmpA (P60) protein was present in similar quantities between cells cultured in vitro and in vivo. This suggests that the presence of the $\sim 35 \mathrm{kDa}$ OmpA (P60) protein is not an artifact due to sample preparation, but there may be processing or degradation occurring in in vitro culture. The OmpA (P60) protein of F. psychrophilum has been extensively 
characterized and suggested to play a potential role in protective immunity (Merle et al. 2003, Dumetz et al. 2007). In these studies, rabbit polyclonal serum was prepared against purified OmpA (P60), and Western blot analysis of crude F. psychrophilum extracts revealed a single band in 1-dimensional electrophoresis (Dumetz et al. 2007). Whether the identification of 2 distinct protein spots exhibiting different spot intensities as OmpA (P60) is a noteworthy finding remains to be determined, but is of importance as this protein has been suggested for vaccine development against $F$. psychrophilum.

The culture of bacteria in iron-limited media has been shown to mimic the in vivo environment (Ebanks et al. 2004). The results of the present study suggest that the culture of Flavobacterium psychrophilum in such conditions mimics the in vivo environment to some extent, but not completely because only 6 of 20 identified proteins shared similar spot intensity changes. It is possible that the $50 \mu \mathrm{M}$ DPD employed in the present study was insufficient to chelate all iron present in the media and certainly, the availability of host nutrients is lacking in artificial media. Growth of the bacterium was inhibited at this concentration, which suggests that iron was limiting; however, the use of higher concentrations of DPD may more accurately mimic the iron availability in vivo. Another explanation is that the analysis was limited to one time point ( $3 \mathrm{~d}$ culture) for iron-limited growth, and it is possible that other changes in the proteome may have occurred at later time points. This was evident in the analysis of $F$. psychrophilum cultured in vivo as several trends in protein spot intensity were identified over the course of the $10 \mathrm{~d}$ experiment (Table 2).

Results from in vivo and iron-limited culture of Flavobacterium psychrophilum did not show increased spot intensities of recognized iron-regulated outer membrane proteins, as has been demonstrated in other bacterial species following culture under these conditions (Colquhoun \& Sorum 1998, Ebanks et al. 2004). Moller et al. (2005b) studied the iron-acquisition mechanisms of $F$. psychrophilum and suggested that it produces siderophores and is capable of using iron from transferrin and hemoglobin. The F. psychrophilum genome contains 5 TonB-dependent outer membrane iron receptors and 2 proteins exhibiting similarity to an iron uptake system of Campylobacter jejuni (Duchaud et al. 2007). Research has also demonstrated that the TonB system of $F$. psychrophilum is important for virulence (Alvarez et al. 2008). It is possible that the quantities of these proteins were not detectable in the whole-cell lysate preparations and/or that the rehydration buffer used for 2D-PAGE was not effective at solubilizing these outer membrane proteins (Molloy et al. 1998). Alternatively, it is also possible that $F$. psychrophilum relies on other mechanisms to obtain iron, such as the release of proteolytic enzymes as suggested by Moller et al. (2005b).

The present study examined the proteome of Flavobacterium psychrophilum when grown in vivo or under iron-limited conditions as a first step to understand the pathogenesis of this bacterium. Future research should focus on the outer membrane proteins, because these are involved in host-pathogen interactions and may also be important for pathogenesis and vaccine development. By enriching for outer membrane proteins, other proteins may be identified that were not present in whole-cell lysates at sufficient quantities for detection in the present study. Additionally, the membrane vesicles, lipopolysaccharide, and glycocalyx produced by $F$. psychrophilum should be examined following growth in vivo. Previously, it was demonstrated that some strains of F. psychrophilum exhibit increased production of membrane vesicles when cultured in iron-limited media and media containing rainbow trout serum (Moller et al. 2005a). The authors further demonstrated that cells exhibit a slight increase in the amount of glycocalyx when cultured in media supplemented with rainbow trout serum (Moller et al. 2005a).

In summary, the combination of growth in ironlimited conditions, use of dialysis tubing chambers for in vivo culture, and proteomics have proven to be useful techniques for identifying Flavobacterium psychrophilum proteins that exhibit changes in protein spot intensities. It is likely that at least some of these proteins are involved in the pathogenesis of this fish pathogen. Future research should be aimed at determining the precise roles of these proteins in the pathogenesis of $F$. psychrophilum and evaluating their potential to provide protection against CWD when used in immunization trials.

Acknowledgements. This research was funded in part by the USDA Small Business Innovation Research (SBIR) program (grant no. 2003-33610-13945) and the Idaho and Washington Aquaculture Initiative USDA-CSREES (award nos. 200334468-14085, 2004-34468-15199). The authors gratefully acknowledge D. Whitten at the Proteomics Core Facility of Michigan State University for assistance with mass spectrometry analysis and protein identification.

\section{LITERATURE CITED}

Alvarez B, Alvarez J, Menendez A, Guijarro JA (2008) A mutant in one of two exbD loci of a TonB system in Flavobacterium psychrophilum shows attenuated virulence and confers protection against cold water disease. Microbiology 154:1144-1151

> Andrews SC, Robinson AK, Rodriguez-Quinones F (2003) Bacterial iron homeostasis. FEMS Microbiol Rev 27:215-237

Aoki M, Kondo M, Nakatsuka Y, Kawai K, Oshima S (2007) Stationary phase culture supernatant containing mem- 
brane vesicles induced immunity to rainbow trout Oncorhynchus mykiss fry syndrome. Vaccine 25:561-569

Bakopoulos V, Hanif A, Poulos K, Galeotti M, Adams A, Dimitriadis GJ (2004) The effect of in vivo growth on the cellular and extracellular components of the marine bacterial pathogen Photobacterium damsela subsp piscicida. J Fish Dis 27:1-13

Blatch GL, Lassle M (1999) The tetratricopeptide repeat: a structural motif mediating protein-protein interactions. Bioessays 21:932-939

Braun TF, Khubbar MK, Saffarini DA, McBride MJ (2005) Flavobacterium johnsoniae gliding motility genes identified by mariner mutagenesis. J Bacteriol 187:6943-6952

> Brown MR, Anwar H, Costerton JW (1988) Surface antigens in vivo: a mirror for vaccine development. Can J Microbiol 34:494-498

Cepeda C, Garcia-Marquez S, Santos Y (2004) Improved growth of Flavobacterium psychrophilum using a new culture medium. Aquaculture 238:75-82

> Chastanet A, Derre I, Nair S, Msadek T (2004) clpB, a novel member of the Listeria monocytogenes CtsR regulon, is involved in virulence but not in general stress tolerance. J Bacteriol 186:1165-1174

Colquhoun D, Sorum H (1998) Outer membrane protein expression during in vivo cultivation of Vibrio salmonicida. Fish Shellfish Immunol 8:367-377

> Crump EM, Burian J, Allen PD, Kay WW (2005) Identification and expression of a host-recognized antigen, FspA, from Flavobacterium psychrophilum. Microbiology 151: 3127-3135

> Crump EM, Burian J, Allen PD, Gale S, Kay WW (2007) Identification of a ribosomal L10-like protein from Flavobacterium psychrophilum as a recombinant vaccine candidate for rainbow trout fry syndrome. J Mol Microbiol Biotechnol 13: $55-64$

Dabo SM, Confer AW, Quijano-Blas RA (2003) Molecular and immunological characterization of Pasteurella multocida serotype A:3 OmpA: evidence of its role in P. multocida interaction with extracellular matrix molecules. Microb Pathog 35:147-157

> Daskalov H, Austin DA, Austin B (1999) An improved growth medium for Flavobacterium psychrophilum. Lett Appl Microbiol 28:297-299

> Delpino MV, Estein SM, Fossati CA, Baldi PC, Cassataro J (2007) Vaccination with Brucella recombinant DnaK and SurA proteins induces protection against Brucella abortus infection in BALB/c mice. Vaccine 25:6721-6729

> Duchaud E, Boussaha M, Loux V, Bernardet JF and others (2007) Complete genome sequence of the fish pathogen Flavobacterium psychrophilum. Nat Biotechnol 25: 763-769

Dumetz F, Duchaud E, LaPatra SE, Le Marrec C, Claverol S, Urdaci MC, Le Henaff M (2006) A protective immune response is generated in rainbow trout by an OmpH-like surface antigen (P18) of Flavobacterium psychrophilum. Appl Environ Microbiol 72:4845-4852

> Dumetz F, Lapatra SE, Duchaud E, Claverol S, Le Henaff M (2007) The Flavobacterium psychrophilum OmpA, an outer membrane glycoprotein, induces a humoral response in rainbow trout. J Appl Microbiol 103:1461-1470

> Dumetz F, Duchaud E, Claverol S, Orieux N, Papillon S, Lapaillerie D, Le Henaff M (2008) Analysis of the Flavobacterium psychrophilum outer-membrane subproteome and identification of new antigenic targets for vaccine by immunomics. Microbiology 154:1793-1801

> Ebanks RO, Dacanay A, Goguen M, Pinto DM, Ross NW (2004) Differential proteomic analysis of Aeromonas salmonicida outer membrane proteins in response to low iron and in vivo growth conditions. Proteomics 4:1074-1085

Ekaza E, Teyssier J, Ouahrani-Bettache S, Liautard JP, Kohler S (2001) Characterization of Brucella suis clpB and $\operatorname{clp} A B$ mutants and participation of the genes in stress responses. J Bacteriol 183:2677-2681

> Havlasova J, Hernychova L, Brychta M, Hubalek M and others (2005) Proteomic analysis of anti-Francisella tularensis LVS antibody response in murine model of tularemia. Proteomics 5:2090-2103

Holt RA, Rohovec JS, Fryer JL (1993) Bacterial coldwater disease. In: Inglis V, Roberts RJ, Bromage NR (eds) Bacterial diseases of fish. Blackwell Scientific Publications, Oxford, p 3-23

Hosogi Y, Duncan MJ (2005) Gene expression in Porphyromonas gingivalis after contact with human epithelial cells. Infect Immun 73:2327-2335

> Hughes V, Smith S, Garcia-Sanchez A, Sales J, Stevenson K (2007) Proteomic comparison of Mycobacterium avium subspecies paratuberculosis grown in vitro and isolated from clinical cases of ovine paratuberculosis. Microbiology 153:196-205

> Jensen ON, Wilm M, Shevchenko A, Mann M (1999) Peptide sequencing of 2-DE gel-isolated proteins by nanoelectrospray tandem mass spectrometry. Methods Mol Biol 112: 571-588

Justice SS, Hunstad DA, Harper JR, Duguay AR and others (2005) Periplasmic peptidyl prolyl cis-trans isomerases are not essential for viability, but SurA is required for pilus biogenesis in Escherichia coli. J Bacteriol 187:7680-7686

Kurupati P, Teh BK, Kumarasinghe G, Poh CL (2006) Identification of vaccine candidate antigens of an ESBL producing Klebsiella pneumoniae clinical strain by immunoproteome analysis. Proteomics 6:836-844

Laemmli UK (1970) Cleavage of structural proteins during the assembly of the head of bacteriophage T4. Nature 227: $680-685$

LaFrentz BR (2007) Identification of immunogenic candidate antigens, proteins expressed in vivo, and development of attenuated strains of Flavobacterium psychrophilum for vaccine development. $\mathrm{PhD}$ dissertation, University of Idaho, Moscow, ID

> LaFrentz BR, LaPatra SE, Jones GR, Congleton JL, Sun B, Cain KD (2002) Characterization of serum and mucosal antibody responses and relative per cent survival in rainbow trout, Oncorhynchus mykiss (Walbaum), following immunization and challenge with Flavobacterium psychrophilum. J Fish Dis 25:703-713

LaFrentz BR, LaPatra SE, Jones GR, Cain KD (2003) Passive immunization of rainbow trout, Oncorhynchus mykiss (Walbaum), against Flavobacterium psychrophilum, the causative agent of bacterial coldwater disease and rainbow trout fry syndrome. J Fish Dis 26:377-384

> LaFrentz BR, LaPatra SE, Jones GR, Cain KD (2004) Protective immunity in rainbow trout Oncorhynchus mykiss following immunization with distinct molecular mass fractions isolated from Flavobacterium psychrophilum. Dis Aquat Org 59:17-26

> Lazar SW, Kolter R (1996) SurA assists the folding of Escherichia coli outer membrane proteins. J Bacteriol 178: 1770-1773

Liu WT, Karavolos MH, Bulmer DM, Allaoui A, Hormaeche RD, Lee JJ, Khan CM (2007) Role of the universal stress protein UspA of Salmonella in growth arrest, stress and virulence. Microb Pathog 42:2-10

> Martínez JL, Casado A, Enríquez R (2004) Experimental infection of Flavobacterium psychrophilum in fins of 
Atlantic salmon Salmo salar revealed by scanning electron microscopy. Dis Aquat Org 59:79-84

Massias B, Dumetz F, Urdaci MC, Le Henaff M (2004) Identification of P18, a surface protein produced by the fish pathogen Flavobacterium psychrophilum. J Appl Microbiol 97:574-580

- Merle C, Faure D, Urdaci MC, Le Henaff M (2003) Purification and characterization of a membrane glycoprotein from the fish pathogen Flavobacterium psychrophilum. J Appl Microbiol 94:1120-1127

Michel C, Antonio D, Hedrick RP (1999) Production of viable cultures of Flavobacterium psychrophilum: approach and control. Res Microbiol 150:351-358

Moller JD, Barnes AC, Dalsgaard I, Ellis AE (2005a) Characterisation of surface blebbing and membrane vesicles produced by Flavobacterium psychrophilum. Dis Aquat Org 64:201-209

Moller JD, Ellis AE, Barnes AC, Dalsgaard I (2005b) Iron acquisition mechanisms of Flavobacterium psychrophiIum. J Fish Dis 28:391-398

Molloy MP, Herbert BR, Walsh BJ, Tyler MI and others (1998) Extraction of membrane proteins by differential solubilization for separation using two-dimensional gel electrophoresis. Electrophoresis 19:837-844

> Nematollahi A, Decostere A, Pasmans F, Haesebrouck F (2003) Flavobacterium psychrophilum infections in salmonid fish. J Fish Dis 26:563-574

Nystrom T, Neidhardt FC (1992) Cloning, mapping and nucleotide sequencing of a gene encoding a universal stress protein in Escherichia coli. Mol Microbiol 6:3187-3198

Obach A, Baudin Laurencin F (1991) Vaccination of rainbow trout Oncorhynchus mykiss against the visceral form of coldwater disease. Dis Aquat Org 12:13-15

Ochoa-Reparaz J, Sesma B, Alvarez M, Jesus Renedo M, Irache JM, Gamazo C (2004) Humoral immune response in hens naturally infected with Salmonella Enteritidis against outer membrane proteins and other surface structural antigens. Vet Res 35:291-298

- Okano S, Shibata Y, Shiroza T, Abiko Y (2006) Proteomicsbased analysis of a counter-oxidative stress system in Porphyromonas gingivalis. Proteomics 6:251-258

Ottemann KM, Miller JF (1997) Roles for motility in bacterialhost interactions. Mol Microbiol 24:1109-1117

> Otto BR, Verweij-Van Vught AMJJ, MacLaren DM (1992) Transferrins and heme-compounds as iron sources for pathogenic bacteria. Crit Rev Microbiol 18:217-233

Poobalane S, Thompson KD, Diab A, Ardó L, Jeney G, Adams A (2008) Protein expression by Aeromonas hydrophila during growth in vitro and in vivo. Microb Pathog 45:60-69

Rahman MH, Kuroda A, Dijkstra JM, Kiryu I, Nakanishi T, Ototake M (2002) The outer membrane fraction of Flavobacterium psychrophilum induces protective immunity in rainbow trout and ayu. Fish Shellfish Immunol 12:169-179

Ross BC, Czajkowski L, Vandenberg KL, Camuglia S and others (2004) Characterization of two outer membrane protein antigens of Porphyromonas gingivalis that are protective in a

Editorial responsibility: Stewart Johnson,

Nanaimo, British Columbia, Canada murine lesion model. Oral Microbiol Immunol 19:6-15

Serino L, Nesta B, Leuzzi R, Fontana MR and others (2007) Identification of a new OmpA-like protein in Neisseria gonorrhoeae involved in the binding to human epithelial cells and in vivo colonization. Mol Microbiol 64:1391-1403

> Shevchenko A, Wilm M, Vorm O, Mann M (1996) Mass spectrometric sequencing of proteins silver-stained polyacrylamide gels. Anal Chem 68:850-858

Smith SG, Mahon V, Lambert MA, Fagan RP (2007) A molecular Swiss army knife: OmpA structure, function and expression. FEMS Microbiol Lett 273:1-11

Squires C, Squires CL (1992) The Clp proteins: proteolysis regulators or molecular chaperones? J Bacteriol 174: 1081-1085

Struve C, Forestier C, Krogfelt KA (2003) Application of a novel multi-screening signature-tagged mutagenesis assay for identification of Klebsiella pneumoniae genes essential in colonization and infection. Microbiology 149:167-176

Sudheesh PS, LaFrentz BR, Call DR, Siems WF, LaPatra SE, Wiens GD, Cain KD (2007) Identification of potential vaccine target antigens by immunoproteomic analysis of a virulent and a non-virulent strain of the fish pathogen Flavobacterium psychrophilum. Dis Aquat Org 74:37-47

Sydenham M, Douce G, Bowe F, Ahmed S, Chatfield S, Dougan G (2000) Salmonella enterica serovar typhimurium surA mutants are attenuated and effective live oral vaccines. Infect Immun 68:1109-1115

Tanaka N, Nakamoto H (1999) HtpG is essential for the thermal stress management in cyanobacteria. FEBS Lett 458: $117-123$

> Thornton JC, Garduno RA, Carlos SJ, Kay WW (1993) Novel antigens expressed by Aeromonas salmonicida grown in vivo. Infect Immun 61:4582-4589

Twine SM, Mykytczuk NC, Petit MD, Shen H, Sjostedt A, Wayne Conlan J, Kelly JF (2006) In vivo proteomic analysis of the intracellular bacterial pathogen, Francisella tularensis, isolated from mouse spleen. Biochem Biophys Res Commun 345:1621-1633

- Vorob'eva LI (2004) Stressors, stress reactions, and survival of bacteria: a review. Appl Biochem Microbiol 40:217-224

> Wang Z, Larocque S, Vinogradov E, Brisson JR and others (2004) Structural studies of the capsular polysaccharide and lipopolysaccharide O-antigen of Aeromonas salmonicida strain 80204-1 produced under in vitro and in vivo growth conditions. Eur J Biochem 271:4507-4516

> Weiss DS, Brotcke A, Henry T, Margolis JJ, Chan K, Monack DM (2007) In vivo negative selection screen identifies genes required for Francisella virulence. Proc Natl Acad Sci USA 104:6037-6042

Wiklund T, Dalsgaard I (2002) Survival of Flavobacterium psychrophilum in rainbow trout (Oncorhynchus mykiss) serum in vitro. Fish Shellfish Immunol 12:141-153

Yuan L, Rodrigues PH, Belanger M, Dunn W Jr, ProgulskeFox A (2007) The Porphyromonas gingivalis clpB gene is involved in cellular invasion in vitro and virulence in vivo. FEMS Immunol Med Microbiol 51:388-398

Submitted: January 12, 2009; Accepted: July 24, 2009

Proofs received from author(s): November 6, 2009 